POLITYKA ENERGETYCZNA - ENERGY POLICY JOURNAL

$2021 \uparrow$ Volume $24 \uparrow$ Issue $3 \uparrow 29-42$

DOI: $10.33223 / \mathrm{epj} / 135770$

Krystian MajchrzaK ${ }^{1}$, Monika PePlowska ${ }^{2}$, Piotr OlczaK $^{3}$

\title{
Heating films as an element of combined photovoltaic and heating systems in residential buildings
}

ABSTRACT: This paper discusses the idea of combining a photovoltaic system with a heating film system to heat residential buildings. The analysis was performed for a newly built single-family house in Warsaw or its vicinity. The authors have selected the size of the photovoltaic installation, calculated the costs incurred by the user for the installation of a hybrid system, which were additionally compared to the cost of installing a gas installation (gas boiler) used for heating the building. The calculations were made for a single-family house with a usable area of $120 \mathrm{~m}^{2}$, the demand for utility energy for heating purposes in the newly built house was in the range of $10-50 \mathrm{kWh} / \mathrm{m}^{2} /$ year. Based on the adopted parameters, the authors evaluated the economic efficiency of both investments (solutions) determining their net present values (NPV). The analysis takes the energy needed only for heating purposes into account.

NPV for a heating system with a gas boiler with an investment outlay EUR 8,000 for buildings purchased for utility energy in the amount of $20 \mathrm{kWh} / \mathrm{m}^{2} /$ year and the price for natural gas EUR $0.04 / \mathrm{kWh}$ will be EUR $-10,500$ (for 15 years, discount rate $\mathrm{r}=3 \%$ ). For the same thermal needs

$\triangle$ Corresponding Author: Piotr Olczak; e-mail: olczak@min-pan.krakow.pl

${ }^{1}$ Mineral and Energy Economy Research Institute of the Polish Academy of Sciences, Kraków, Poland; Instaway Institute, Warszawa, Poland; e-mail: krystian.majchrzak@instaway.pl

2 Mineral and Energy Economy Research Institute of the Polish Academy of Sciences, Kraków, Poland; ORCID iD: 0000-0001-9150-7525; e-mail: monika@min-pan.krakow.pl

${ }^{3}$ Mineral and Energy Economy Research Institute of the Polish Academy of Sciences, Kraków, Poland; ORCID iD: 0000-0002-4926-0845; e-mail: olczak@min-pan.krakow.pl

2021. The Author(s). This is an open-access article distributed under the terms of the Creative Commons Attribution-ShareAlike International License (CC BY-SA 4.0, http://creativecommons.org/licenses/by-sa/4.0/), which permits use, distribution, and reproduction in any medium, provided that the Article is properly cited. 
(energy required) of the building, NPV for heating films + photovoltaic (HF + PV) will amount to EUR 8,100. Comparing the variants will get a EUR 2,400 higher NPV for HF + PV. With a utility energy demand for heating purpose of $50 \mathrm{kWh} / \mathrm{m}^{2} /$ year and gas heating installation investment cost of EUR 7,000, the NPV for both variants will be equal for natural gas price $=$ EUR $0.035 / \mathrm{kWh}$.

KEYWORDS: renewable energy sources, photovoltaics, solar energy, sustainable building, heating films

\section{Introduction}

In the EU climate and energy package, the European Commission has set targets for the reduction of gas emissions (mainly carbon dioxide). These documents lay down 2020 and 2030 targets for each of the Member States. The assumed target for 2030 was to reduce greenhouse gas emissions by at least $40 \%$ (compared to 1990 levels) with the plan to achieve the goal of reducing emissions by $80-95 \%$ by 2050 . However, the currently announced strategies ("Stepping up Europe's 2030 climate ambition - Investing in a climate-neutral future for the benefit of our people" (COM (2020) 562)) assume a significant increase in these restrictions. The reduction of greenhouse gas emissions in the European Union is to reach at least $55 \%$ below 1990 levels by 2030 (Koval et al. 2019a; Koval et al. 2019b). These assumptions take the issues of emissions and removals into account and propose a legally binding target of net zero greenhouse gas emissions by 2050 and a commitment to climate neutrality. In this document, the Commission took into account, among others, the fact that large emissions reductions have come from closing coal power stations and cleaning up energy-intensive industries, while it proved harder to reduce emissions from transport and agriculture and in buildings, where particular challenges exist (Kryzia and Pepłowska 2019). Therefore, it is necessary to intensify EU activities in all economic sectors. Long lead times in key sectors such as land use and transport require acceleration in the coming decade - otherwise the changes required after 2030 will have to happen unrealistically quickly.

The policy implemented in the European Union determines the development of the Polish energy policy, the objectives of which for many years have been: ensuring energy security, increasing the competitiveness of the economy and its energy efficiency, as well as environmental protection (Ministry of Climate 2020; Shmygol et al. 2020). According to the information published by the Ministry of Climate and Environment on September 8, 2020, the Minister of Climate submitted the updated draft of Polish Energy Policy until 2040 for the opinion of the Coordination Committee for Development Policy and for the opinion of the Minister for Regional Development on compliance with the medium-term strategy of the country. This document is not currently available to the public, it will only be made public once a decision is made. The only available document is a summary of the new project available on the website of the Ministry of Climate and Environment (Ministry of Climate 2020). As announced by the Minister of Climate 
and Environment, the updated "Polish Energy Policy until 2040" recognizes that the transformation will cover many sectors. As announced in the above document, the goals to be achieved include an increase in the share of renewable energy sources (RES) in all sectors and technologies and at least a $23 \%$ share of renewable energy sources in gross final energy consumption by 2030. achieve share of at least a 32,28, and $14 \%$ share of renewable energy sources in the power is expected to be achieved (assuming the development of wind and PV energy), heating, and transport sectors, respectively. Another target is a significant increase in the installed capacity of PV, estimated at approximately 5-7 GW in 2030 and 10-16 GW ten years later. Therefore, new ecological solutions introduced in every branch of the economy are still sought and strongly supported by the EU budget.

When analyzing social behavior, one can come across a growing social awareness of the progressing climate change and the possibility of reducing air pollution. When designing new residential buildings, both single-family and multi-family, one of the initial steps is to choose a heating system. Photovoltaic systems may be a part of the system being an alternative for traditional heat sources. Consumers are more and more interested in environmentally friendly heating systems. Meanwhile, solar photovoltaic systems are becoming increasingly popular, both in Poland and Europe (Żelazna et al. 2020). There is a growing demand, but, most importantly, the discussed solution is environmentally friendly. In addition, through the introduction of the RES Act, the prospect of free solar power, energy independence, and additional earnings is very attractive. According to this act, the owner of the installation may become a prosumer of renewable energy and sell the energy generated from his own installation to the grid (Mirowski and Sornek 2015). Pursuant to Article 30, Paragraph 1 of the Construction Law Act, the installation of photovoltaic panels does not require a building permit and there is no obligation to report such an installation. In light of the above, the installation of photovoltaic panels is an attractive option. Among the modern and relatively rare hybrid home heating systems using photovoltaics, heating films, which, due to the growing demand for the development of photovoltaics, are a promising alternative to conventional solutions, deserve special attention.

The thermal needs of buildings in Poland are negatively correlated with the potential of photovoltaic energy production. The following settlement is helpful for prosumers in this respect: the prosumer can store virtually in the grid depending on the prosumer coefficient: 0.8 ( $20 \%$ energy loss) for PV installations up to $10 \mathrm{kWp}$ and 0.7 for installations in the range of $10-50 \mathrm{kWp}$. The prosumer factor applies to a prosumer installation for a maximum of 15 years, therefore the period of effective use of the installation was assumed at the level of 15 years (Jasiński et al. 2021; Olczak et al. 2021). 


\section{Installation of heating systems using heating films}

In Poland, due to the underdeveloped market, heating film systems are relatively rare. These films emit heat using the radiation of electromagnetic waves working in the infrared (wavelength of about $1000 \mathrm{~nm}$ ) (Tytko 2019). Heating films provide the same functionalities as other resistive (heating cables, heating mats) or radiative (infrared radiators) electric heating systems.

Polish brand Red Snake heating films were used as an example of heating films used in household heating. Red Snake is a thin film with a thickness of $0.45 \mathrm{~mm}$, a fabric heating element, and a mixture of carbon fibers and carbon paste. Figure 1 shows installation of floor heating film.

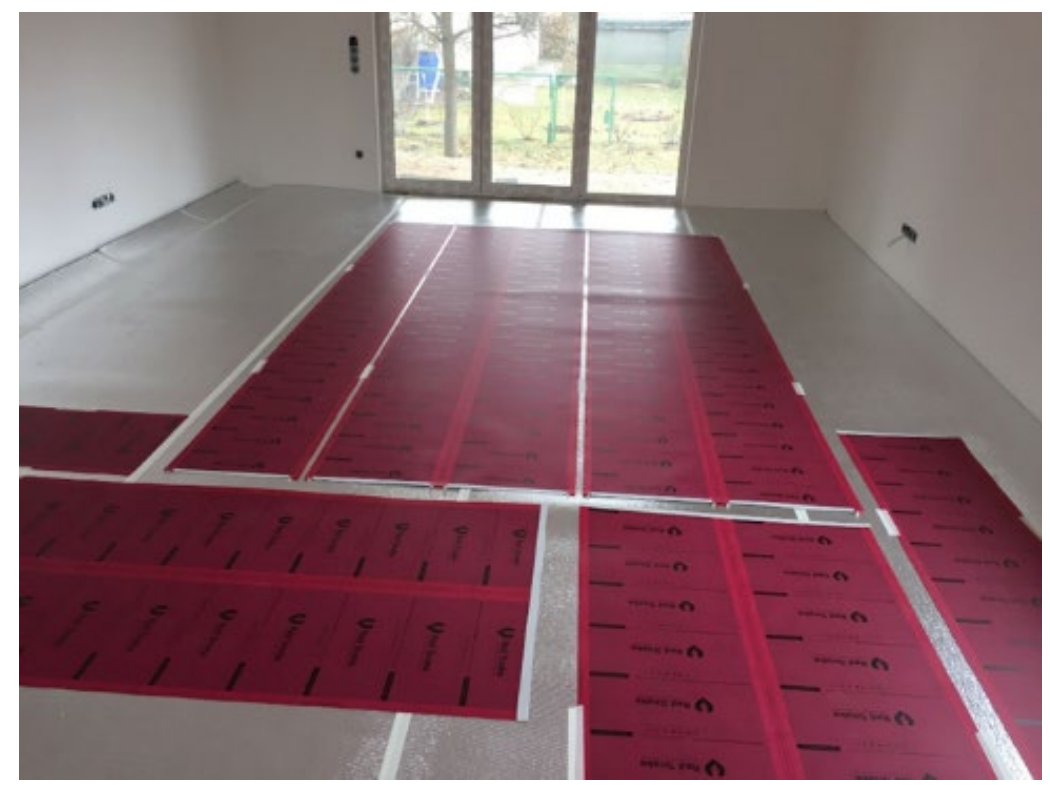

Fig. 1. Red Snake heating film underfloor installation Source: own photo

Rys. 1. Przykład instalacji folii grzewczej Red Snake pod podłogą

The main advantage of the proposed solution is that a boiler room and fuel storage area are not required. If, in addition, heating films are used with photovoltaics as a part of house heating system, we can become self-sufficient after some time (on an annual basis) and reduce the variable heating costs. 


\section{Research methodology}

In this paper, the authors performed calculations for a newly built single-family house, with a heated area (HA) of $120 \mathrm{~m}^{2}$, using a combination of photovoltaics and heating film systems. The energy demand was assumed to be entirely balanced by the photovoltaic system, and the usable energy needed for heating was assumed to range from 10 to $50 \mathrm{kWh} / \mathrm{m}^{2} /$ year (different building insulation standards).

In order to estimate the energy from the photovoltaic installation, the location of the potential house was determined and the amount of insolation in a given area (Fig. 2), which, under Polish conditions is approx. $1000 \mathrm{kWh} / \mathrm{m}^{2} /$ year (Chwieduk 2009; JRC European Comission 2017), was analyzed.

The proposed combination of photovoltaic and heating film systems was compared to a gas installation.

A specific location was designated due to the importance of the volume of electricity production from photovoltaic panels. Analyzing the two solutions proposed for heating a newly built single-family house $\left(120 \mathrm{~m}^{2}\right)$ located in Warsaw, the costs of both investments were compared in the first stage (Table 1):

(1) Hybrid heating - photovoltaic and heating film systems (HF + PV),

(2) Gas heating - gas boiler with radiator water heating system (G).

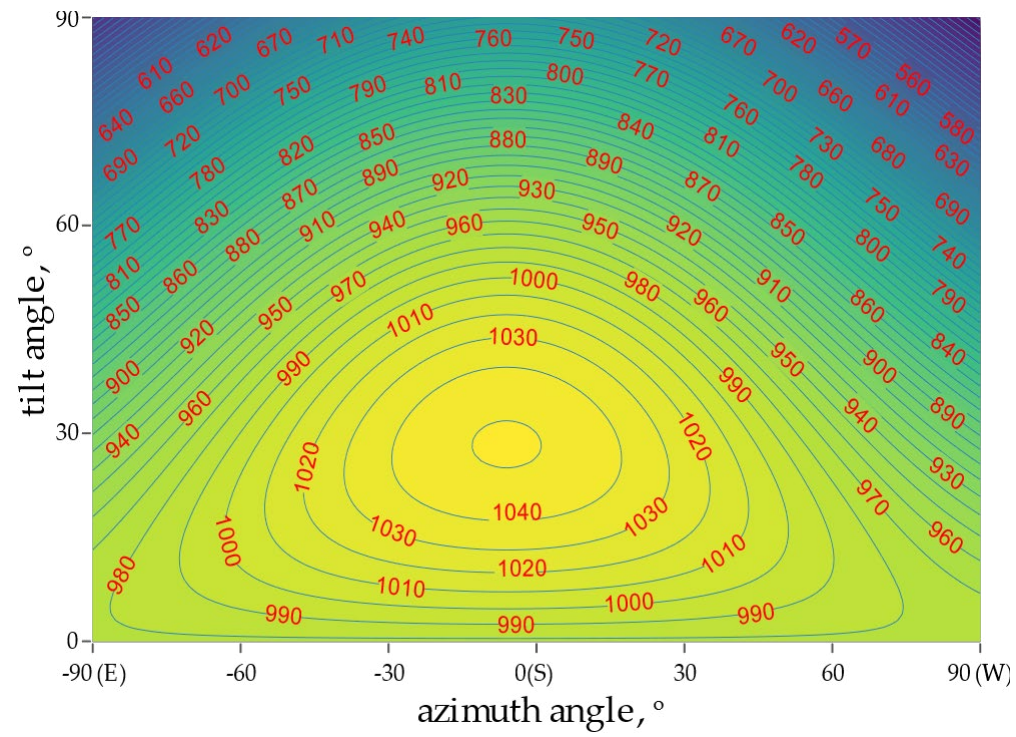

Fig. 2. Available insolation $\left[\mathrm{kWh} / \mathrm{m}^{2} /\right.$ year] for Warsaw depending on surface angle and azimuth. Own work based on the Typical Meteorological Year for Warszawa-Okęcie Source: (The Ministry of Development 2019)

Rys. 2. Dostępne nasłonecznienie [kWh/m²/rok] dla Warszawy jako zależność od kąta nachylenia i azymutu 
TABLE 1. Comparison of investment costs (I0) [EUR]

TABELA 1. Porównanie nakładów inwestycyjnych (I0) [EUR]

\begin{tabular}{|l|c|c|}
\hline \multicolumn{1}{|c|}{ Investment } & HF + PV variant & G variant \\
\hline Boiler room, chimney, and gas installation & & 3,330 \\
\hline Boiler & & 2,220 \\
\hline Central heating & & 3,330 \\
\hline Heating films + control & 5,330 & 0 \\
\hline Photovoltaics (for Energy Us. $=50 \mathrm{kWh} / \mathrm{m}^{2} /$ year $)-, 7 \mathrm{kWp} "$ & 6,440 & 0 \\
\hline Total & 11,770 & 8,880 \\
\hline
\end{tabular}

Source: own work based on the market offer (Columbus Energy 2021; Gas boilers 2021).

The amount of final energy needed to supply heating films is determined by the following formula:

$$
E K_{H F+P V}=\frac{H A \cdot H U E}{\eta_{H F+P V}}
$$

where:

$E K_{H F+P V}-$ energy required to supply the heating films [kWh/year],

$H A \quad-$ the heating area of the building $\left[\mathrm{m}^{2}\right]$,

HUE - the useful energy demand for heating purposes $\left[\mathrm{kWh} / \mathrm{m}^{2} /\right.$ year $]$,

$H_{H F+P V}-$ the average annual efficiency of the heating foil system [percentage value].

The amount of fuel (gas expressed in $\mathrm{kWh}$ - final energy) needed to supply the gas boiler was determined using the following formula:

$$
E K_{G}=\frac{H A \cdot H U E}{\eta_{G} \cdot \eta_{I}}
$$

where:

$E K_{G} \quad$ - energy to be supplied to the gas boiler [kWh/year],

$H A \quad-$ the heating area of the building $\left[\mathrm{m}^{2}\right]$,

$H U E$ - the useful energy demand for heating purposes $\left[\mathrm{kWh} / \mathrm{m}^{2} /\right.$ year],

$\eta_{G} \quad-$ the average annual efficiency of the gas boiler system: $94 \%$, Regulation of the Minister of Infrastructure and Development of 27 February 2015 (Journal of Laws 2015, item 376),

$\eta_{I} \quad-$ the average annual efficiency of the system: $80 \%$, Regulation of the Minister of In frastructure and Development of 27 February 2015 (Journal of Laws 2015, item 376). 
The values introduced into equations 1 and 2 are presented in Table 2. The average values for a new single-family house were assumed.

TABLE 2. Parameters used for the comparison of heating systems

TABELA 2. Parametry użyte do porównania systemów grzewczych

\begin{tabular}{|c|c|c|c|}
\hline Parameter & HF+PV variant & G variant & Unit \\
\hline$H A$ & 120 & 120 & $\mathrm{~m}^{2}$ \\
\hline$E U o g$ & 50 & 50 & $\mathrm{kWh} / \mathrm{m}^{2} /$ year \\
\hline$H$ & 98 & 94 & $\%$ \\
\hline$\eta I$ & & 80 & $\%$ \\
\hline$E K$ & 6,122 & 7,978 & $\mathrm{kWh} /$ year \\
\hline
\end{tabular}

Source: own study.

Table 3 presents the operating costs for both solutions. It should be noted that, according to the manufacturers of heating films, offering a 25-year product warranty, operating costs are close to zero (in the case of cooperation with PV). On the other hand, the costs of the film installed in the ceiling are slightly lower than the costs of the floor installation and are estimated at about EUR $28 / \mathrm{m}^{2}$, while the estimated price of floor installation is about EUR $45 / \mathrm{m}^{2}$.

TABLE 3. Summary of operating costs of both variants. Own work based on PGNiG prices, W-3 tariff: (Natural Gas Price 2021)

TABELA 3. Podsumowanie kosztów operacyjnych obu wariantów

\begin{tabular}{|l|c|c|}
\hline \multicolumn{1}{|c|}{ Investment } & HF + PV solution & G Solution \\
\hline Maintenance (MC) & 20 & 20 \\
\hline Equipment replacement (MC) & 40 & 40 \\
\hline Other costs (MC) & 20 & 20 \\
\hline Gas energy [EUR/kWh] & 0 & 0.033 \\
\hline Total per year & 90 & 330 \\
\hline
\end{tabular}

Source: own study.

With the final energy ratio for heating in the interval from 10 to $80 \mathrm{kWh} / \mathrm{m}^{2}$ and the useful production from photovoltaics (taking into account the 0.8 prosumer conversion factor - annual unevenness of heating needs vs. energy production from photovoltaics - Fig. 4) of $800 \mathrm{kWh} / \mathrm{kWp} / \mathrm{year}$, the required power of the installation will be $7 \mathrm{kWp}$ (for $\mathrm{HUE} \approx 50 \mathrm{kWh} / \mathrm{m}^{2} /$ year). According to the manufacturer's information, the cost of the film is PLN 5,330 and the price of photovoltaics is EUR 920/kWp. Thus, adding the fixed costs of the installation (around PLN 330), the estimated price of the installation in case of solution $1(\mathrm{HF}+\mathrm{PV})$ is EUR 11,770. 
Based on the adopted parameters, the authors evaluated the economic efficiency of both investments (solutions) by determining the net present value (NPV). As a result of the performed calculations, the information was obtained that in the case of heating film the NPV does not depend on the gas price, but only on the amount of energy demand, while in the case of photovoltaics, the NPV depends on the gas price.

The following assumptions were made:

$\downarrow$ lifetime of installation, $n=15$ years,

$\downarrow$ discount rate $(r) 3 \%$ (Kryzia et al. 2020),

$\checkmark$ initial investment (Table 3).

Net Present Value (NPV) was calculated based on equation no. 3

$$
N P V=\left[\sum_{t=1}^{n} \frac{C F_{t}}{(1+r)^{t}}\right]-I 0
$$

where:

$C F_{t} \quad-$ the cash flow in the year $t$ [EUR],

$t \quad-$ year of the analysis,

$n \quad-$ system lifetime - comparison time (20 years) [year],

for natural gas:

$$
C F_{t}=-\left(\frac{E K_{G}}{c v n g} \cdot \text { gas price }+M C_{G}\right)\left[\frac{\text { EUR }}{\text { year }}\right]
$$

where:

$C F_{t} \quad-$ the cash flow in the year $t$ [EUR],

cvng - calorific value of natural gas (Matuszewska et al. 2017; Szurlej et al. 2014),

$M C_{G}$ - other maintenance or operational cost [EUR/year],

for heating films $+\mathrm{PV}$ :

$$
C F_{t}=-\left(M C_{H F+P V}\right)\left[\frac{\mathrm{EUR}}{\mathrm{year}}\right]
$$

where:

$C F_{t} \quad-$ the cash flow in the year $t$ [EUR],

$M C_{H F+P V^{-}}$other maintenance or operational costs [EUR/year].

The following ranges are used in the calculations:

४ For $I 0_{G}$ : from EUR 6,000 to 9,000 ,

$\checkmark$ For gas price: from EUR 0.02 to $0.1 / \mathrm{kWh}$,

$\checkmark$ HUE from 10 to $50 \mathrm{kWh} / \mathrm{m}^{2} /$ year.

36 
Difference between twice NPV variants can be calculate by equation no. 6 .

$$
\text { diff. } N P V=N P V(\text { for } H F+P V)-N P V(\text { for } G)[\mathrm{EUR}]
$$

\section{Results}

The results in the form of cash flows for natural gas heating systems in individual years are presented in Figure 3a. For the "HF+PV" variant, the cash flow is EUR -50/year and it does not practically depend on the size of the installation or the price of gas. NPV results for HF+PV are presented in Figure $3 b$.
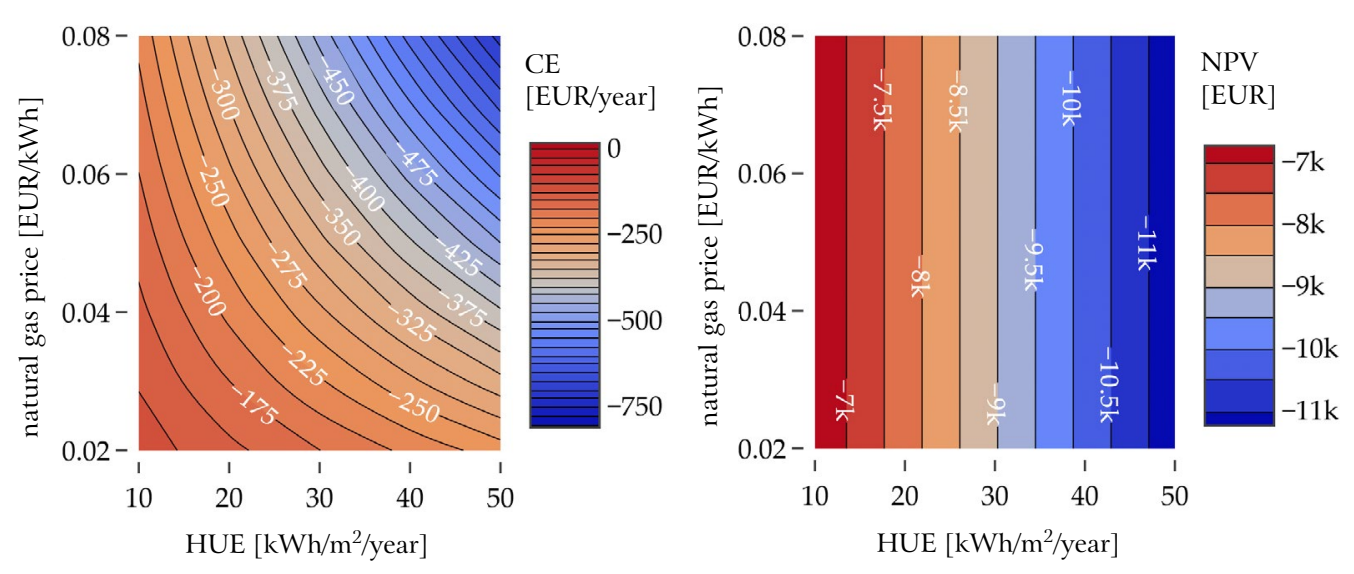

Fig. 3. Cash flow for heating system with gas boiler (left side), NPV for heating films: HF+PV (right side)

Rys. 3. Przepływy finansowe dla systemu grzewczego z kotłem gazowym (strona lewa), NPV dla systemu folii grzewczych: HF + PV (prawa strona)

NPV for HF+PV variant does not depend on natural gas price (equation 5) and also for electricity price in case of proper calculation of $\mathrm{PV}$ installation size. In the case of gas heating, the NPV values for different initial investment costs are presented in Figure 4.

The negative NPVs are related to the fact that in all cases they refer to the costs of a new building, hence no savings made.

Then, the difference between NPV for HF+PV and NPV for gas heating was calculated. The results for various variants of investment costs are shown in Figures 6-7. 

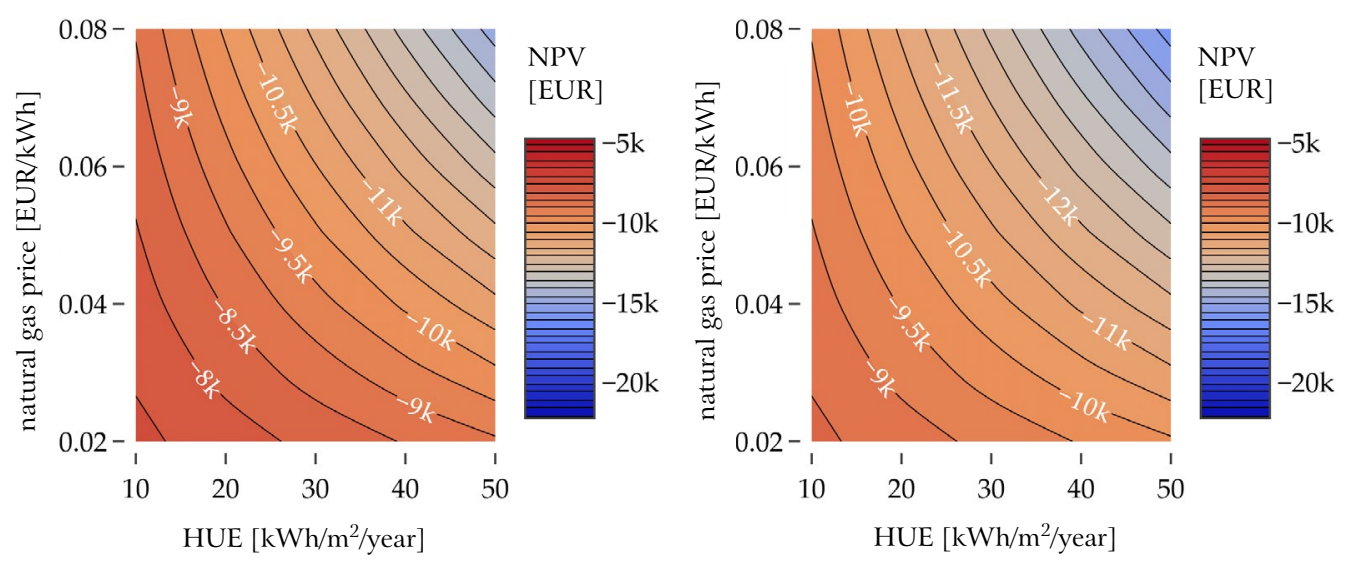

Fig. 4. NPV for gas heating for $I 0_{G}=$ EUR 6,000 (left) and 7,000 (right)

Rys. 4. NPV dla ogrzewania gazowego dla $I 0_{G}=6000$ euro (lewa strona) i 7000 euro (strona prawa)
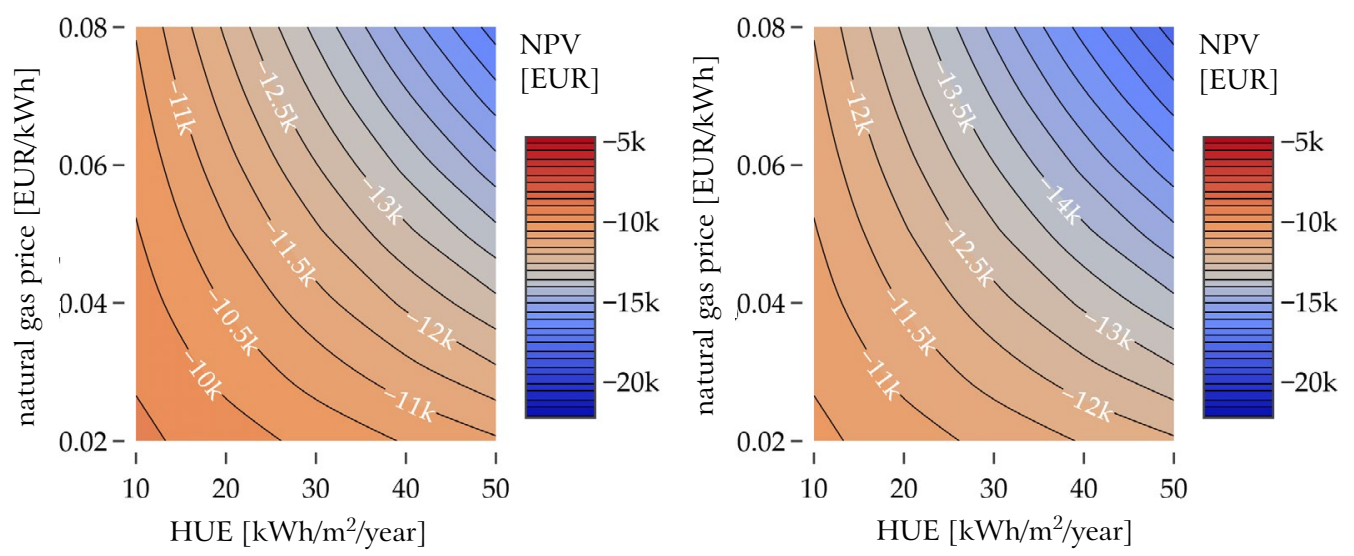

Fig. 5. NPV for gas heating for $10_{G}=$ EUR 8,000 (left) and 9,000 (right)

Rys. 5. NPV dla ogrzewania gazowego dla $I 0_{G}=8000$ euro (lewa strona) i 9000 euro (strona prawa)

Interpretation for the price of heating installation + gas boiler + gas installation $\left(I 0_{G}\right)$ of:

$\downarrow$ EUR 6,000 with a gas price of EUR $0.04 / \mathrm{kWh}$ and a useful energy demand of $30 \mathrm{kWh} / \mathrm{m}^{2}$ / year, the HF+PV system will increase NPV by EUR 350 over 15 years.

$\checkmark$ EUR 7,000 with a gas price of EUR $0.04 / \mathrm{kWh}$ and a useful energy demand of $30 \mathrm{kWh} / \mathrm{m}^{2}$ / year, the HF+PV system will increase NPV by EUR 1,400 over 15 years.

$\checkmark$ EUR 8,000 with a gas price of EUR $0.04 / \mathrm{kWh}$ and a useful energy demand of $30 \mathrm{kWh} / \mathrm{m}^{2}$ / year, the HF+PV system will increase NPV by EUR 2,200 over 15 years.

$\checkmark$ EUR 9,000 with a gas price of EUR $0.04 / \mathrm{kWh}$ and a useful energy demand of $30 \mathrm{kWh} / \mathrm{m}^{2}$ / year, the HF+PV system will increase NPV by EUR 3,300 over 15 years. 

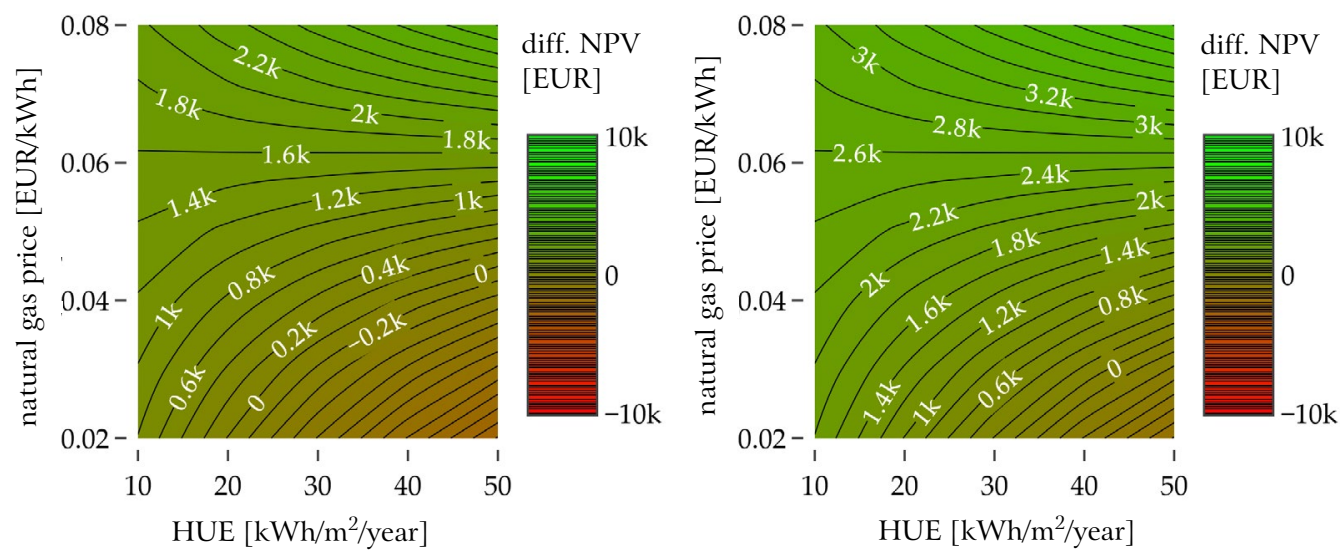

Fig. 6. NPV difference for gas heating and HF+PV for $10_{G}=\mathrm{EUR} 6,000$ (left) and 7,000 (right)

Rys. 6. Różnica NPV dla ogrzewania gazowego i HF+PV dla $I 0_{G}=6000$ euro (lewa strona) i 7000 euro (strona prawa)
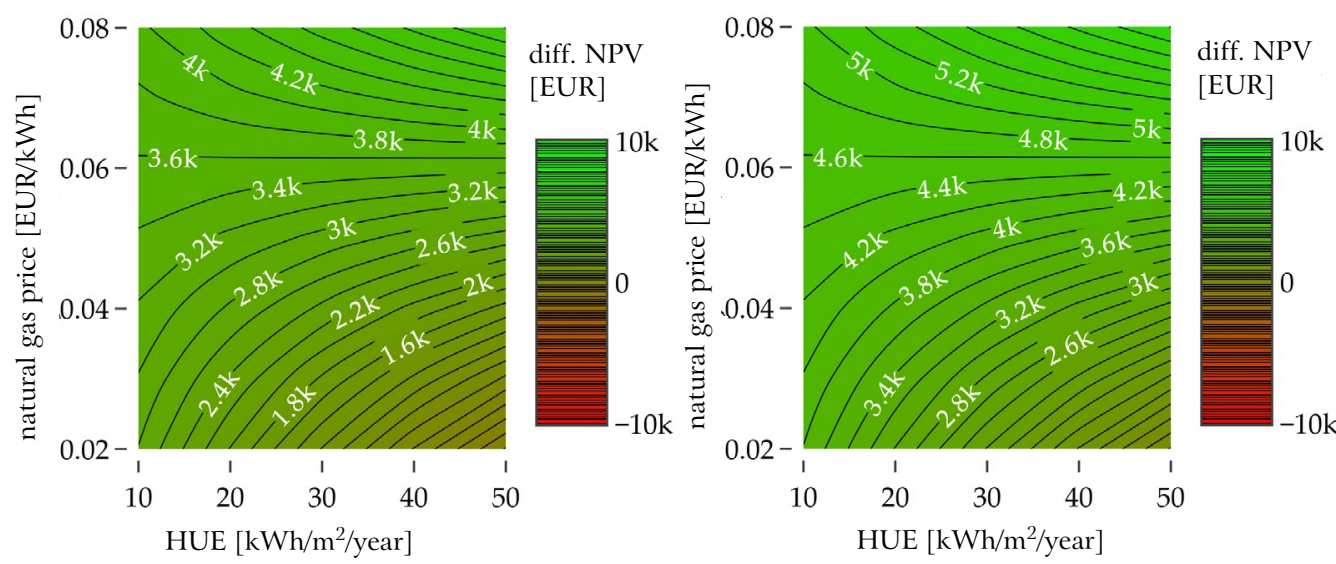

Fig. 7. NPV difference for gas heating and $\mathrm{HF}+\mathrm{PV}$ for $10_{G}=\mathrm{EUR} 8,000$ (left) and 9,000 (right)

Rys. 7. Różnica NPV dla ogrzewania gazowego i HF+PV dla $I 0_{G}=8000$ euro (lewa strona) i 9000 euro (strona prawa)

\section{Conclusions}

The need to move towards a low-carbon economy is inevitable due to the adopted greenhouse gas emission targets. One part of the process is adapting heat sources to renewable energy sources. The use of the proposed idea of combining a photovoltaic system with a heating film system is a new solution with great potential. With the growing demand for green heating investments, 
this solution may compete with currently popular solutions. In addition, as this solution becomes widespread, it can be estimated that increased competition in the market will reduce the price of the technology.

NPV for a heating system with a gas boiler with an investment outlay of $I 0_{G}=$ EUR 8,000 for buildings purchased for utility energy in the amount of $20 \mathrm{kWh} / \mathrm{m}^{2} /$ year and the price for natural gas $0.04 \mathrm{EUR} / \mathrm{kWh}$ will be EUR -10,500 (for 15 years, rate discount $\mathrm{r}=3 \%$ ). For the same thermal needs of the building, NPV for heating films + PV will amount to EUR -8100. Comparing the variants, the variants will get a 2400 Euro higher NPV for HF + PV. With a utility energy demand for heating of $50 \mathrm{kWh} / \mathrm{m}^{2} /$ year $I 0_{G}=$ EUR 7,000 , the NPV for both sides will be equal for natural gas price $=$ EUR $0.035 / \mathrm{kWh}$.

\section{References}

Chwieduk, D. 2009. Recommendation on modelling of solar energy incident on a building envelope. Renewable Energy 34(3), pp. 736-741.

Columbus Energy 2021. Photovoltaic. [Online] https://columbusenergy.pl/ [Accessed: 2021-02-15].

$\operatorname{COM}(2020) 562$ final. Communication from the Commission to the European Parliament, the Council, the European Economic and Social Committee and the Committee of the Regions. Stepping up Europe's 2030 climate ambition. Investing in a climate-neutral future for the benefit of our people. [Online] https://eur-lex.europa.eu/legal-content/EN/TXT/?uri=CELEX\%3A52020DC0562 [Accssessed: 2021-05-14].

Gas boilers 2021. [Online] https://kotly.pl/kotly/ [Accessed: 2021-02-16].

Journal of Laws 2015, item 376. Ordinance of the Minister of Infrastructure and Development of February 27, 2015 On the methodology for determining the energy performance of a building or part of a building and energy performance certificates (Dz.U. 2015, poz. 376, Rozporzadzenie Ministra Infrastruktury i Rozwoju z dnia 27 lutego 2015 r. W sprawie metodologii wyznaczania charakterystyki energetycznej budynku lub częśsi budynku oraz świadectw charakterystyki energetycznej). Warszawa (in Polish).

JRC European Comission 2017. Photovoltaic Geographical Information System (PVGIS).

Koval et al. 2019a - Koval, V., Sribna, Y. and GaSKa, K. 2019. Energy Cooperation Ukraine-Poland to Strengthen Energy Security. E3S Web of Conferences 132, DOI: 10.1051/e3sconf/201913201009.

Koval et al. 2019b - Koval, V., Sribna, Y., Mykolenko, O. and Vdovenko, N. 2019. Environmentalconcept of energy security solutions of local communities based on energy logistics. $19^{\text {th }}$ International Multidisciplinary Scientific GeoConference SGEM 2019, 19(5.3), pp. 283-290, DOI: 10.5593/ sgem2019/5.3/S21.036.

Kryzia, D. and Peplowska, M. 2019. The impact of measures aimed at reducing low-stack emission in Poland on the energy efficiency and household emission of pollutants. Polityka Energetyczna - Energy Policy Journal 22(2), pp. 121-132, DOI: 10.33223/epj/109912.

Kryzia et al. 2020 - Kryzia, D., Kopacz, M. and Kryzia, K. 2020. The Valuation of the Operational Flexibility of the Energy Investment Project Based on a Gas-Fired Power Plant. Energies 13(7), DOI: $10.3390 /$ en 13071567.

MatuszewsKa et al. 2017 - MatusZewsKa, D., Kuta, M. and GóRSKi, J. 2017. Cogeneration - Development and prospect in Polish energy sector. E3S Web of Conferences 14, 01021, DOI: 10.1051/e3sconf/20171401021. 
Ministry of Climate 2020. Ministry of Climate and Environment 2020. Poland's energy policy until 2040 (Polityka energetyczna Polski do 2040 r.). [Online] https://www.gov.pl/web/klimat/minister-kurtyka-polityka-energetyczna-polski-do-2040-r-udziela-odpowiedzi-na-najwazniejsze-wyzwania-stojace-przed-polska-energetyka-w-najblizszych-dziesiecioleciach [Accessed: 2021-01-21] (in Polish).

Ministry of Development 2019. Typical Reference Year (Typowy rok referencyjny). [Online] https:// archiwum.miir.gov.pl/strony/zadania/budownictwo/charakterystyka-energetyczna-budynkow/ dane-do-obliczen-energetycznych-budynkow-1/ [Accessed: 2020-08-10] (in Polish).

Mirowski, T. and Sornek, K. 2015. Potential of prosumer power engineering in Poland by example of micro PV installation in private construction (Potencjat energetyki prosumenckiej w Polsce na przyktadzie mikroinstalacji fotowoltaicznych $w$ budownictwie indywidualnym). Polityka Energetyczna - Energy Policy Journal 18(2), pp. 73-84 (in Polish).

Natural Gas Price 2021. [Online] http://www.cena-pradu.pl/gaz.html [Accessed: 2021-02-15].

Shmygol et al. 2020 - Shmygol, N., Schiavone, F., Trokhymets, O., Pawliszczy, D., Koval, V., ZavGORODNIY, R. and VorfolomeIEv, A. 2020. Model for assessing and implementing resource-efficient strategy of industry. CEUR Workshop Proceedings, 2713.

Szurlej et al. 2014 - Szurlej, A., Kamiński, J., Janusz, P., Iwicki, K. and Mirowski, T. 2014. Gas-fired power generation in Poland and energy security (Rozwój energetyki gazowej w Polsce a bezpieczeństwo energetyczne). Rynek Energii 6, pp. 33-38 (in Polish).

TYтко, R. 2019. Heating the building by foil and electrical matts (Ogrzewanie budynku za pomoca folii i mat elektrycznych). Aura 8, pp. 18-21 (in Polish).

Żelazna et al. 2020 - Żelazna, A., Golębiowska, J., Zdyb, A. and Pawıowski, A. 2020. A hybrid vs. on-grid photovoltaic system: Multicriteria analysis of environmental, economic, and technical aspects in life cycle perspective. Energies 13(15), 3978, DOI: 10.3390/en13153978.

Krystian Majchrzak, Monika PePlowska, Piotr Olczak

\section{Folie grzewcze jako element współpracy fotowoltaiki z systemem grzewczym w domach jednorodzinnych}

\section{Streszczenie}

W niniejszym artykule zaprezentowano możliwości ogrzewania budynku mieszkalnego z zastosowaniem hybrydowego współdziałania systemu fotowoltaiki wraz z systemem folii grzewczych. Analizę przeprowadzono dla nowo wybudowanego domu jednorodzinnego w okolicach Warszawy. Autorzy dokonali wyboru wielkości instalacji fotowoltaicznej, obliczyli koszty poniesione przez użytkownika w celu montażu systemu hybrydowego, które dodatkowo porównali do kosztów montażu instalacji gazowej (kocioł gazowy) służącej do ogrzewania niniejszego budynku.

Obliczenia wykonano dla domu jednorodzinnego o powierzchni użytkowej $120 \mathrm{~m}^{2}$, zapotrzebowanie na energię użytkową do celów grzewczych w zakresie $10-50 \mathrm{kWh} / \mathrm{m}^{2} /$ rok. 
Na podstawie przyjętych parametrów autorzy ocenili efektywność ekonomiczną obu inwestycji (rozwiązań: fotowoltaika + folie grzewcze, ogrzewanie gazowe) wyznaczając ich wartości bieżące netto (NPV). $\mathrm{W}$ analizie uwzględniono tylko energię potrzebną na cele grzewcze.

NPV dla instalacji grzewczej z kotłem gazowym o nakładzie inwestycyjnym 8000 EUR dla budynku o zapotrzebowaniu na energię użytkową w ilości $20 \mathrm{kWh} / \mathrm{m}^{2} /$ rok i cenie za gaz ziemny $0,04 \mathrm{EUR} / \mathrm{kWh}$ wyniesie -10 500 EUR (na 15 lat, stopa dyskonta $r=3 \%$ ). Dla analogicznych potrzeb cieplnych budynku, NPV dla folii grzewczych + fotowoltaika (HF + PV) wyniesie -8100 EUR. Porównując warianty, wyższe NPV o 2400 EUR zostanie osiągnięte dla wariantu HF + PV. W przypadku zapotrzebowania na energię użytkową na potrzeby grzewcze na poziomie $50 \mathrm{kWh} / \mathrm{m}^{2} / \mathrm{rok}$, przy nakładach inwestycyjnych $7000 \mathrm{EUR}$. wartości NPV dla obu wariantów będą równe przy cenie gazu ziemnego 0,035 EUR/kWh.

SŁowa KLUCzowE: fotowoltaika, odnawialne źródła energii, energia słoneczna, budownictwo ekologiczne, folie grzewcze 